\title{
Дослідження структури виробничого ризику на робочих місцях працівників із інвалідністю
}

\footnotetext{
Карина Данова * А; Вікторія Малишева А; Олег Богатов ${ }^{\text {; }}$ Ольга Ченчева ${ }^{\mathrm{C}}$

А Харківський національний університет міського господарства імені О.М. Бекетова, вул. Маршала Бажанова, 17, м. Харків, 61002, Україна

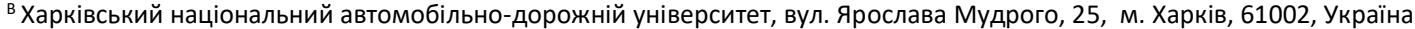

с Кременчуцький національний університет імені Михайла Остроградського, вул. Першотравнева, 20, м. Кременчук, 39600, Україна
}

Received: November 07, 2020 | Revised: December 05, 2020 | Accepted: December 31, 2020

DOI: $10.33445 /$ sds.2020.10.6.2

\begin{abstract}
Анотація
Соціальна спрямованість бізнесу $\epsilon$ сучасним світовим трендом, за якого корпорації приділяють підвищену увагу соціальним, екологічним аспектам своєї діяльності, намагаючись зменшити несприятливий вплив бізнес-процесів на оточення та підвищуючи при цьому рівень соціальної безпеки. Цей підхід реалізується, у тому числі, у залученні на робочі місця представників соціально уразливих верств населення, зокрема, осіб із інвалідністю, а також створенні належних та безпечних умов праці для усіх працівників на робочих місцях. При цьому, має бути приділено особливу увагу питанням організації безпеки праці представників уразливих груп, зокрема, осіб із інвалідністю, що $\epsilon$ надзвичайно важливим елементом підвищення ефективності загальної системи менеджменту безпеки на підприємстві.

Наукова стаття присвячена розгляду актуального питання підвищення рівня безпеки на робочих місцях працівників із інвалідністю шляхом розробки методичних основ ідентифікування небезпек та оцінювання ризиків в умовах підприємства на базі аналізу міжнародного стандарту ДСTV IEC/ISO 31010:2013, а також проєкту Методики проведення роботодавцем заходів з безпеки та гігієни праці на основі ризикоорієнтованого підходу. Роботодавець, як особа, яка, відповідно до законодавства, відповідає у цілому за забезпечення належного рівня безпеки на робочих місцях, $є$ зацікавленим у впровадженні ефективних профілактичних заходів щодо попередження нещасних випадків та професійних захворювань, при цьому ризикорієнтований підхід визнаний найбільш ефективним способом досягнення цієї мети. У статті проаналізовані алгоритми процедури оцінювання виробничих ризиків та запропонований підхід до групування ризиків за принципом характеру дії на працівника, місцем виникнення, що дозволяє адаптувати процедуру до оцінювання ризиків на робочих місцях різних груп працівників, зокрема, із інвалідністю, та врахувати різні стани осіб, які безпосередньо зайняті у виробничому процесі.
\end{abstract}

Ключові слова: особа із інвалідністю, безпека, ризикорієнтований підхід.

\section{Постановка проблеми}

Останніми роками в Україні спостерігається тенденція до збільшення уваги щодо організації трудової зайнятості осіб із інвалідністю на підприємствах різних форм власності та видів діяльності. Надання робочих місць особам із інвалідністю дозволяє не лише вирішувати низку соціально-економічних питань, але й сприяє вдосконаленню систем менеджменту організації, підвищує загальний рівень охорони праці.

Проте організація трудової зайнятості осіб із інвалідністю потребує ретельного підходу до вирішення питань забезпечення безпеки, при цьому найбільш ефективним рішенням $\epsilon$ реалізація ризикорієнтованого підходу на

\footnotetext{
* Corresponding author: в.о. зав. кафедри, доцент кафедри, к.т.н., доцент, e-mail: Karyna.Danova@kname.edu.ua, ORCID: 0000-0002-1994-703X
} 
робочих місцях, адже Директива № 89/391/ЄЕС Ради щодо запровадження заходів заохочення поліпшення безпеки та охорони здоров'я працівників на роботі [1], імплементація якої $€$ важливим елементом адаптації вітчизняної законодавчої бази до європейської, визначає ризикорієнтований підхід у забезпеченні безпеки на робочих місцях як пріоритетний, що, у свою чергу, знайшло відображення у Концепції реформування системи управління охороною праці в Україні [2-3].

Враховуючи те, що законодавство України, зокрема Закон України «Про охорону праці» [4], визначає повну відповідальність роботодавця за створення безпечних умов праці (ст. 4), яка реалізується через належне функціонування системи управління охороною праці (ст. 13), саме роботодавець має забезпечити ефективний механізм реалізації ризикорієнтованого підходу щодо попередження нещасних випадків та професійних захворювань на робочих місцях працівників. Це викликає необхідність відповідного методичного забезпечення процесу оцінювання ризиків, зокрема на робочих місцях уразливих груп працівників.

Державною службою України з питань праці оприлюднений проєкт Методики проведення роботодавцем заходів з безпеки та гігієни праці на основі ризикорієнтованого підходу [5], яка встановлює мінімальні вимоги щодо проведення оцінки ризиків на робочому місці, розробки та здійснення заходів, необхідних для захисту здоров'я та безпеки працівників. Методика [5] визначає основні етапи оцінювання ризиків на робочих місцях працівників, включаючи із уразливими групами, до яких належать особи із інвалідністю. Враховуючи наявні обмеження життєдіяльності та уразливість в аспекті виробничого травматизму та професійних захворювань, оцінювання ризиків на робочих місцях даної групи працівників має відбуватися із урахуванням цих особливостей.

\section{Аналіз останніх досліджень та публікацій}

Із прийняттям Директиви № 89/391/ЄЕС [1] усі країни - члени Європейського союзу імплементували положення щодо ризикорієнтованого підходу до національної нормативно-правової бази. У Німеччині ще до прийняття Директиви Закон про безпеку та гігієну праці («Arbeitsschutzgesetz») від 1996 p. зобов'язував роботодавців визначати необхідні заходи з охорони праці шляхом проведення оцінки ризиків, яким робітники піддаються на роботі. При цьому встановлювалася необхідність враховувати всі джерела ризиків, включаючи психосоціальні фактори, і аналізувати вжиті заходи на предмет їх ефективності. Результати оцінки, заходи, що були впроваджені, а також їх оцінка повинні бути задокументовані [6].

Більшість країн Європейського союзу також мали свої рекомендації, які, незважаючи на відмінності в деталях, в основному мали загальний підхід: інвентаризація типових робочих місць і / або робочих операцій в компанії і перевірка їх на наявність професійних небезпек, які можуть мати фізичний, хімічний, біологічний, механічний або психосоціальний характер; оцінювання кожної з виявлених небезпек 3 точки зору рівня ризику, який вона фактично представляє для співробітників. Якщо ризик неприйнятно високий, необхідно вжити заходів для його усунення або мінімізації [6].

У статті [7] зазначається, що у США демографічні тенденції, технологічні процеси, матеріали та спосіб організації трудової діяльності знаходяться у стані змін, що, у свою чергу, призводить до відходу від стандартних трудових відносин та збільшення частки використання незалежних підрядників і тимчасових працівників. Проте такі зміни негативно позначаються на рівні безпеки праці, використанні засобів індивідуального захисту, а також доступності таких пільг, як страхування здоров'я або оплачувана відпустка. Оцінка ризиків визначається як основний метод прийняття 
рішень в області гігієни праці для багатьох типів небезпек (хімічних, фізичних, мікробних, радіологічних, ергономічних і т. п.). Прийняття рішень на основі ризиків включає три етапи: формулювання проблеми і визначення її обсягу; планування і проведення оцінки ризиків; і управління ризиками. Основний процес оцінки ризику включає: ідентифікація небезпек; оцінка «доза-реакція»; оцінка впливу і характеристика ризику. Отримана в результаті характеристика ризиків призначена для використання при розробці заходів або політик щодо зниження впливу і ризику на робочих місцях працівників. У той же час законодавчі акти США стосовно працевлаштування осіб із інвалідністю, зокрема, [8], встановлюють обмеження і вимоги щодо медичних оглядів працівників і запитів, пов'язаних з інвалідністю. Згідно [9], такі запити та періодичні медичні огляди заборонені до оформлення людини на роботу, але можуть проводитися після того, як пропозицію про роботу було зроблено, а також до та після початку трудової діяльності. Для з'ясування відповідності працівника у США розроблено кілька типів тестів у сфері здоров'я та безпеки, пов'язаних 3 визначенням придатності до роботи, які не потрапляють під категорію медичних обстежень у відповідності з ADA [8] та включають: тести на використання заборонених наркотиків, тести на фізичну вправність, а також психологічні тести. При цьому зазначається, що брак інформації про стан працівника створює додаткові ризики у аспекті охорони праці в організаціях.

у статті [10] аналізується питання небезпеки уразливих категорій працівників, зокрема, працівників, які нещодавно почали працювати на робочому місці. Зазначається, що підвищений ризик травм серед працівників, які мають недостатній досвід у контексті виконання професійних обов'язків на даному підприємстві, викликає особливе занепокоєння цієї групи працівників, а також тих, хто наймається на тимчасову роботу, тому що, переходячи з роботи на роботу, вони постійно піддаються значному ризику наразитися на небезпеку. Це пояснюється поєднанням недостатнього вивчення методів виявлення та контролю небезпек, а також відсутністю ефективного навчання з охорони праці. Зусилля щодо зниження виробничого травматизму включають виявлення факторів ризику, а також реалізацію профілактичних програм для усунення небезпек або зниження ризиків на робочому місці.

Поряд із працівниками, які не мають достатнього досвіду, працівники із інвалідністю також відносяться до представників уразливих груп. В контексті виробничої безпеки та гігієни праці сучасне визначення вразливих працівників надається у [11] - це “особи, хто більшою мірою, ніж більшість працівників, піддається впливу умов, небезпечних для здоров'я або безпеки, і які не в змозі змінити ці умови". Проведені дослідження впливу уразливості працівників на рівень безпеки праці показали, що ризик отримання травми був найбільшим серед тих, хто вважав себе вразливим у контексті виробничої безпеки у поєднанні із недостатнім приділенням уваги до організації охорони праці 3 боку безпосереднього керівника. Встановлено, що якщо взяти до уваги вік, стать працівника, тип трудових відносин, особливості робочого місця і галузь діяльності, ризик отримання фізичних травм був як мінімум в 3,5 рази вище серед тих, хто відчував як вразливість у аспекті охорони праці, так і відсутність підтримки з боку наглядових органів, у порівнянні із особами, не схильними до уразливості щодо безпеки на робочих місцях та належним ставленням безпосереднього керівника до питань охорони праці. Отримані результати підтверджують важливість приділення уваги питанню організації охорони праці на робочих місцях працівників, зокрема тих, що належать до уразливих груп.

\section{Постановка завдання}

Метою статті $\epsilon$ аналіз основних етапів оцінювання ризиків, що передбачені 


\begin{tabular}{llll}
\hline проєктом Методики проведення & [12], а також розробка методичних основ \\
роботодавцем заходів з безпеки та гігієни & оцінювання ризику на робочих місцях \\
праці на основі ризикоорієнтованого підходу & працівників уразливих груп, зокрема осіб із \\
[5] й стандартом ДСТУ IEC/ISO 31010:2013 & інвалідністю.
\end{tabular}

\section{Виклад основного матеріалу}

При вирішенні питання організації безпеки праці працівників із обмеженими можливостями в умовах підприємства важливо оцінювати ризики, пов'язані із трудовою діяльністю. У процесі управління ризиками визначається не лише перелік небезпек, які присутні на тому чи іншому робочому місці, але й засоби захисту, які $\epsilon$ найбільш ефективними для даних умов. Ризикорієнтований підхід реалізується за певним алгоритмом. Загальна послідовність оцінювання та керування ризиком визначається ДСТУ IEC/ISO 31010:2013 та включає у себе наступні етапи [12]:

- обмінювання інформацією та консультування;

- установлення оточення;

- ідентифікування, аналізування оцінювання ризику;

- обробляння ризику;

- моніторинг та критичне осмислення результатів, що отримано.

Проєкт Методики проведення роботодавцем заходів з безпеки та гігієни праці на основі ризикоорієнтованого підходу також ґрунтується на процесному підході та включає у себе наступні етапи [5]:

- виявлення небезпек;

- визначення працівників (або інших осіб), які можуть зазнавати ризику через ці небезпеки;

- оцінювання відповідного ризику - якісне та (або) кількісне;

- розгляд можливості усунення ризику;

- якщо його усунути неможливо прийняття рішення про необхідність запровадження подальших заходів 3 попередження чи зменшення ризику.

Порівнюючи дані підходи щодо управління виробничими ризиками, можна зробити висновок, що вони мають певні відмінності у переліку етапів та їх черговості.
При цьому Методика [5] встановлює мінімальні вимоги щодо проведення роботодавцем оцінки ризиків на робочому місці, тобто $\epsilon$ спрощеною процедурою. Проте, її перевагою $€$ те, що окремим етапом встановлена необхідність визначення кола працівників чи інших осіб, які можуть бути уражені внаслідок реалізації певної небезпеки. Цей акцент є особливо важливим при проведенні дослідження виробничих ризиків на робочих місцях працівників із особливими потребами та представників інших уразливих у аспекті безпеки груп.

у будь-якому випадку, для ефективного оцінювання ризиків необхідно проводити ґрунтовний аналіз виробничого обладнання, технологічних процесів та оточення з метою виявлення небезпек, що можуть знайти свою реалізацію у вигляді нещасних випадків чи погіршення стану здоров'я працівників, які зайняті у трудовому процесі.

Орієнтуючись на останні тенденції у сфері оцінювання ризиків, у якості переліку небезпек можна прийняти перелік, зазначений у іншому проєкті нормативного документа - Ідентифікаторі виробничих небезпек і створюваних ними виробничих та професійних ризиків на об'єктах різних галузей економіки [13]. Даний документ вводить наступні групи виробничих небезпек: механічні небезпеки; електричні небезпеки; термічні небезпеки; небезпеки, створювані шумом; небезпеки, створювані вібрацією; небезпеки, створювані випромінюванням; небезпеки, створювані матеріалами та речовинами; небезпеки через недотримання конструктором ергонометричних принципів; небезпеки, пов'язані з середовищем, в якому експлуатується машина; комбінація небезпек тощо. Розділення небезпечних та шкідливих факторів на групи дозволяє підвищити рівень систематизації етапу ідентифікування 
небезпек на робочих місцях працівників.

у процесі оцінювання ризиків важливо залучати до співпраці різних стейкхолдерів для врахування усіх інтересів зацікавлених осіб, зокрема із обмеженими можливостями, організовувати ефективне обмінювання інформацією та консультування з тим, щоб з'ясувати особливі потреби представників різних груп працівників.

При аналізуванні оточення мають бути враховані основні чинники, що характеризують зовнішне та внутрішне середовище організації, а також обсяги, методологія та критерії ризику. Це дозволяє врахувати основні засади політики організації, вимоги законодавства, а також визначити ресурси, необхідні для проведення процедури оцінювання ризиків роботодавцем в умовах підприємства.

Як зазначалося вище, процес ідентифікування небезпек має бути структурований, щоб забезпечити максимальне охоплення усіх можливих ризиків на робочих місцях. Стандарт [12] вказує на необхідність приділення підвищеної уваги різним станам, у яких можуть знаходитися працівники та інші стейкхолдери, а також відхиленням організаційного характеру, пов'язаним із технічними та програмними засобами.

Таким чином, оцінювання ризиків із урахуванням особливих потреб уразливих груп працівників, зокрема осіб із інвалідністю, дозволяє деталізувати окремі групи ризиків, більш ґрунтовно з'ясувати їх походження, а значить - зробити процес оцінювання ризиків більш ефективним. При цьому структура ризиків може бути різною. Наприклад, при оцінюванні ризиків на робочому місці працівника із інвалідністю за основу можна обрати наступні групи ризиків:

1) ризики, пов'язані із можливим травмуванням працівника, зокрема, із інвалідністю, на робочому місці внаслідок впливу небезпечних виробничих факторів, $R_{\mathrm{p}}$;

2) ризики, пов'язані із погіршенням стану здоров'я (погіршення перебігу основного захворювання, поява нового захворювання) внаслідок впливу шкідливих виробничих факторів, $R_{\mathrm{h}}$;

3) ризики, пов'язані із травмуванням працівника, зокрема, із інвалідністю, на території підприємства, у приміщеннях харчування та санітарного призначення, $R_{\mathrm{t}}$.

Ризик, пов'язаний із можливим травмуванням працівника, зокрема, із інвалідністю, безпосередньо на робочому місці внаслідок реалізації небезпечного фактора певної групи визначається як:

$$
R_{p}=I \sum_{i=1}^{n} P_{p_{i}} \cdot Q_{p_{i}},
$$

де I - інтегральний показник обмеження життєдіяльності певного працівника із інвалідністю, що визначається за висновками медико-соціальної експертної комісії після обстеження стану здоров'я особи [14]; для особи без обмежень життєдіяльності $I=1$;

$P_{\mathrm{p} 1}-$ ймовірність травмування працівника із інвалідністю внаслідок реалізації небезпек механічного характеру внаслідок роботи виробничого обладнання, здійснення технологічних процесів;

$P_{\mathrm{p} 2}-$ ймовірність травмування працівника із інвалідністю внаслідок реалізації небезпек електричного характеру;

$P_{\mathrm{p} 3}$ - ймовірність травмування працівника із інвалідністю внаслідок реалізації небезпек термічного характеру;

$P_{\mathrm{p} 4}$ - ймовірність травмування працівника із інвалідністю внаслідок реалізації небезпек, що викликана контактом із матеріалами та речовинами, наявність яких обумовлена технологічним процесом;

$P_{\mathrm{p} 5}-$ ймовірність травмування працівника із інвалідністю внаслідок невідповідностей психофізіологічного характеру, а саме: неадекватна обмеженням життєдіяльності конструкція або розташування пристроїв візуальної індикації, ручного управління; монотонність праці; неадекватне фізичне чи психологічне навантаження; незручна поза та iн.;

$Q_{\mathrm{pi}}$ - тяжкість наслідків реалізації $i$-ї небажаної події для особи із інвалідністю, внаслідок реалізації небезпек відповідно механічного, електричного, термічного, психофізіологічного характеру, а також 
внаслідок контакту із матеріалами та речовинами, що присутні на робочому місці.

Ризики, пов'язані із погіршенням стану здоров'я внаслідок впливу шкідливих виробничих факторів (погіршення перебігу основного захворювання, поява нового захворювання) на робочому місці, $R_{\mathrm{h}}$, визначаються як

$$
R_{h}=I \sum_{j=1}^{m} P_{h_{j}} \cdot Q_{h_{j}},
$$

де $P_{\mathrm{h} 1}$ - ймовірність погіршення самопочуття працівника із інвалідністю, появи нового захворювання чи загострення захворювання, що існує, внаслідок реалізації небезпек, пов'язаних із невідповідностями мікрокліматичних показників;

$P_{\mathrm{h} 2}$ - ймовірність погіршення самопочуття працівника із інвалідністю, появи нового захворювання чи загострення захворювання, що існує, внаслідок наявності на робочому місці невідповідностей віброакустичного характеру;

$P_{\mathrm{h} 3}$ - ймовірність погіршення самопочуття працівника із інвалідністю, появи нового захворювання чи загострення захворювання, що існує, внаслідок наявності на робочому місці невідповідностей у контексті випромінювання (іонізуючого, електромагнітного та ін.);

$P_{\mathrm{h} 4}$ - ймовірність погіршення самопочуття працівника із інвалідністю, появи нового захворювання чи загострення захворювання, що існує, внаслідок наявності на робочому місці невідповідностей інших параметрів виробничого середовища, зокрема запиленості, загазованості та ін.;

$Q_{\text {hj }}$ - тяжкість наслідків реалізації небажаної події для особи із інвалідністю внаслідок реалізації небезпек, викликаних невідповідностями мікрокліматичного, віброакустичного характеру, а також внаслідок впливу джерел випромінювання, запиленості та загазованості повітря робочої зони.

Ризики, пов'язані із травмуванням працівника із інвалідністю на території підприємства, у приміщеннях харчування та санітарного призначення

$$
R_{t}=I \sum_{g=1}^{l} \sum_{k=1}^{s} P_{t_{g}} \cdot P_{t_{k}} \cdot Q_{t_{g}},
$$

де $P_{\mathrm{tg}}-$ ймовірність травмування працівника у даному місці території підприємства чи санітарно-побутовому приміщенні $g$-ю небезпекою, що визначається статистичними даними чи експертною оцінкою;

$P_{\mathrm{tk}}-$ ймовірність перебування працівника із інвалідністю у $k$-му місці території чи приміщенні;

$Q_{\mathrm{tg}}$ - тяжкість наслідків реалізації небажаної події для особи із інвалідністю внаслідок травмування на території підприємства, у санітарно-побутових та інших приміщеннях внаслідок впливу $g$-ї небезпеки.

Таким чином, даний підхід дозволяє деталізувати особливості впливу небезпек виробничого обладнання, процесів та середовища на представників уразливих груп, зокрема осіб із інвалідністю, та підвищити рівень ефективності реалізації ризикорієнтованого підходу. Використання інтегрального показника обмеження життєдіяльності працівника із інвалідністю дозволяє врахувати стійкі функціональні зміни у стані здоров'я, а також ступінь їх вираженості, що $€$ важливим для врахування усіх аспектів організації трудової діяльності цієї та інших груп працівників, які потребують підвищеної уваги у контексті охорони праці.

\section{Висновки}

Забезпечення безпечних та здорових умов праці задля збереження житя й здоров'я працівників $\epsilon$ запорукою сталого розвитку будь-якого підприємства, організації. Належний рівень безпеки персоналу та виробничих процесів формує підґрунтя для економічної ефективності виробництва, підвищення рівня конкурентоспроможності та інвестиційної привабливості підприємства як для вітчизняних, так й для іноземних інвесторів. Соціальна спрямованість бізнесу, як важливого напряму діяльності, демонструється, у тому 
числі, у створенні належних та безпечних умов праці для усіх працівників. При цьому, увага до питань безпеки праці представників уразливих груп, зокрема, осіб із інвалідністю, $\epsilon$ надзвичайно важливим елементом підвищення ефективності загальної системи менеджменту безпеки на підприємстві.

Ризикорієнтований підхід, як провідний у напряму забезпечення безпеки на робочих місцях працівників, реалізується шляхом послідовного виконання певних процедур. У статті проаналізовані два алгоритми оцінювання ризиків - на базі чинного стандарту ДСТУ IEC/ISO 31010:2013 [12], а також проєкту Методики проведення роботодавцем заходів 3 безпеки та гігієни праці на основі ризикоорієнтованого підходу [5], яка визначає мінімальні вимоги до проведення роботодавцем оцінки ризиків на робочому місці. Проведений аналіз показав, що зазначені алгоритми мають деякі відмінності у змісті та черговості певних етапів. У контексті оцінювання ризиків на робочих місцях працівників, зокрема із інвалідністю, використання алгоритму, що ґрунтується на
ДСТУ IEC/ISO 31010:2013, є доцільнішим, тому що передбачає підготовчий період, який включає у себе консультування та встановлення оточення. Це важливо, оскільки прийом працівника із обмеженими можливостями на роботу здійснюється на основі рекомендацій Медико-соціальної експертної комісії, яка надає висновок про наявність обмежень житєдіяльності за певними категоріями, а також ступінь їх вираженості, що передує безпосередній ідентифікації небезпек. У той же час проєкт Методики [5] робить акцент на етапі визначення працівників (або інших осіб), які можуть зазнавати ризику через певні небезпеки, що дозволяє зосередити увагу на різних групах стейкхолдерів.

\section{У статті пропонується проводити} ідентифікацію небезпек та подальше оцінювання ризиків шляхом об'єднання їх у групи за принципом характеру дії на працівника, місцем виникнення що дозволяє адаптувати процедуру оцінювання ризиків для різних груп працівників, зокрема, із інвалідністю.

\section{Список використаних джерел}

1. Директива № 89/391/ЄЕС Ради щодо запровадження заходів заохочення поліпшення безпеки та охорони здоров'я працівників на роботі [Електронний ресурс]: станом на 22 жовтня 2008 р. / Верховна Рада України - URL: https://zakon.rada.gov.ua/laws/show/994_b 23\#Text (дата звернення 20.09.2020). Назва з екрана.

2. Данова К.В., Малишева В.В. Врахування функціональних обмежень при оцінюванні ризику травмування працівника із інвалідністю / К. В. Данова, В.В. Малишева // Комунальне господарство міст. - Вип. 156. - Х.: ХНУМГ, 2020. - С. 165-169.

3. Концепція реформування системи управління охороною праці [Електронний ресурс]: станом на 12 груд. 2018 р. / Верховна Рада України [Електронний pecypc]. - URL: https://zakon.rada.gov.ua/ laws/show/989-2018-\%D1\%80?lang=ru (дата звернення 11.06.2020). - Назва 3 екрана.

4. Закон України «Про охорону праці» / Верховна Рада України [Електронний pecypc]. - URL: http://zakon2.rada.gov.ua/ laws/show/2694-12 (дата звернення 21.02.2019). - Назва з екрана.

5. Методика проведення роботодавцем заходів з безпеки та гігієни праці на основі ризикоорієнтованого підходу. Проєкт нормативного документу / Офіційний сайт Державної служби України з питань праці [Електронний ресурс]. - URL: https://dsp.gov.ua/ (дата звернення 20.09.2020). - Назва з екрана.

6. Lenhardt U., Beck D. Prevalence and quality of workplace risk assessments - Findings from a representative company survey in Germany / U. Lenhardt, D. Beck // Safety Science. Volume 86, July 2016, pages 48-56. URL: https://www.sciencedirect.com/science/arti 
cle/pii/S0925753516000618.

7. Fox, M. A., Spicer, K., Chosewood, L. C., Susi, P., Johns, D. O., \& Dotson, G. S. (2018). Implications of applying cumulative risk assessment to the workplace / M. A. Fox et al. // Environment international. - Volume 115, pages 230-238. URL: https://www.ncbi. nlm.nih.gov/pmc/articles/PMC6108318/.

8. Americans with Disabilities Act (42 USC 42 U.S.C. § 12101 and amendments P.L. 110325) URL: https://www.ada.gov/pubs/ ada.htm, Accessed date: 27092020.

9. U.S. Equal Employment Opportunity Commission (EEOC), 2000. Enforcement guidance: disability-related inquiries and medical examinations of employees under the Americans with Disabilities Act. URL: https://www.eeoc.gov/policy/docs/guidanc e-inquiries.html, Accessed date: 27092020.

10. Marie Laberge, Bénédicte Calvet, Marc Fredette, Nassim Tabet, AurélieTondoux, Dolores Bayard, Curtis Bresline Unexpected events: Learning opportunities or injury risks for apprentices in low-skilled jobs? A pilot study // Safety Science. - Volume 86 , July 2016, Pages 1-9 URL: https://www. sciencedirect.com/science/article/pii/S0925

\section{4.}

11. Yanar, B., Lay, M., Smith, P.M., 2019. The Interplay Between Supervisor Safety Support and Occupational Health and Safety Vulnerability on Work Injury. Safety and Health at Work.. doi: 10.1016/j.shaw.2018.11.001 URL: https:// pubmed.ncbi.nlm.nih.gov/31297279/.

12. ДСТУ IEC/ISO 31010:2013 Керування ризиком. Методи загального оцінювання ризику (IEC/ISO 31010:2013, IDT). - К. : Мінекономрозвитку України, 2015.

13. Ідентифікатор виробничих небезпек i створювані ними виробничі та професійні ризики на об'єктах різних галузей економіки. Проєкт нормативного документу / Офіційний сайт Державної служби України з питань праці [Електронний ресурс]. - URL: https://dsp.gov.ua/ (дата звернення 20.09.2020). - Назва з екрана.

14. Данова К.В. Функціональні обмеження осіб із інвалідністю в аспекті оцінки рівня працездатності та безпеки праці / К.В. Данова // Комунальне господарство міст. Вип. 7 (146). - Х.: ХНУМГ, 2019. - С. 133 137.

\title{
Исследование структуры производственного риска на рабочих местах работников с инвалидностью
}

\footnotetext{
Карина Данова*А; Виктория МалышеваА

*Corresponding author: и.о. зав. кафедры, доц., к.т.н., доц., е-mail: Karyna.Danova@kname.edu.ua, ORCID: 0000-0002-1994-703X А Харьковский национальный университет городского хозяйства имени А.Н. Бекетова, ул. Маршала Бажанова, 17, г. Харьков, 61002, Украина

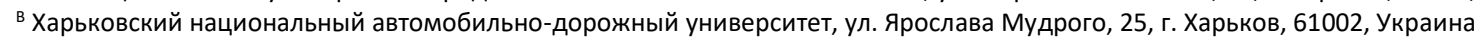

с Кременчугский национальный университет имени Михаила Остроградского, ул. Первомайская, 20, г. Кременчуг, 39600, Украина
}

\begin{abstract}
Аннотация
Социальная направленность бизнеса является современным мировым трендом, при котором корпорации уделяют повышенное внимание социальным, экологическим аспектам своей деятельности, пытаясь уменьшить неблагоприятное влияние бизнеспроцессов на окружение и повышая при этом уровень социальной безопасности. Этот подход реализуется, в том числе, в привлечении на рабочие места представителей социально уязвимых слоев населения, в частности, лиц с ограниченными возможностями, а также создании надлежащих и безопасных условий труда для всех работников на рабочих местах. При этом должно быть уделено особое внимание вопросам организации безопасности труда представителей уязвимых групп, в частности, лиц с ограниченными возможностями, что является чрезвычайно важным элементом повышения эффективности общей системы менеджмента безопасности на предприятии.

Научная статья посвящена рассмотрению актуального вопроса повышения уровня
\end{abstract}


безопасности на рабочих местах работников с инвалидностью путем разработки методических основ идентификации опасностей и оценки рисков в условиях предприятия на базе анализа международного стандарта ДСТУ IEC / ISO 31010: 2013, а также проекта Методики проведения работодателем мероприятий по безопасности и гигиены труда на основе риск ориентированного подхода. Работодатель, как лицо, в соответствии с законодательством отвечающее в целом за обеспечение надлежащего уровня безопасности на рабочих местах, заинтересован во внедрении эффективных профилактических мероприятий по предупреждению несчастных случаев $и$ профессиональных заболеваний, при этом риск ориентированный подход признан наиболее эффективным способом достижения этой цели. В статье проанализированы алгоритмы процедуры оценки производственных рисков и предложен подход к группировке рисков по принципу характера воздействия на работника, места возникновения, а также влияния на окружающих, что позволяет адаптировать процедуру к оценке рисков на рабочих местах различных групп работников, в частности, с инвалидностью, и учесть различные состояния лиц, непосредственно занятых в производственном процессе.

Ключевые слова: лицо с инвалидностью, безопасность, риск ориентированный подход.

\title{
Research of the occupational risk at workplaces of workers with disabilities
}

\author{
Karyna Danova*A; Viktoriya Malysheva ${ }^{A}$; Oleg Bogatov ${ }^{B}$; Olha Chencheva ${ }^{C}$ \\ ${ }^{*}$ Corresponding author: acting head of Occupational and Life Safety Department, associate professor, candidate of technical sciences, e-mail: \\ Karyna.Danova@kname.edu.ua, ORCID: 0000-0002-1994-703X \\ A O.M. Beketov National University of Urban Economy in Kharkiv, 17, Marshal Bazhanov Street, Kharkiv, 61002, Ukraine \\ ${ }^{B}$ Kharkiv national automobile-highway university, 25, Yaroslava Mudrogo street, Kharkiv, 61002, Ukraine \\ c Kremenchuk Mykhailo Ostrogradskyi national university, 20, Pershotravneva Street, Kremenchuk, 39600, Ukraine
}

\begin{abstract}
The social orientation of business is a modern global trend, in which corporations pay more attention to the social, environmental aspects of their activities, trying to reduce the negative influence of business processes on the environment and increase the level of social safety. This approach is implemented including the involvement to the workplaces the representatives of socially vulnerable groups, in particular, people with disabilities, as well as creating appropriate and safe working conditions for all workers at the workplace. At the same time, special attention should be paid to the organization of occupational safety of vulnerable groups, in particular, people with disabilities, which are an extremely important element in improving the effectiveness of the overall safety management system at the enterprise.

The scientific article is devoted to the topical issue of improving the level of safety at the workplaces of workers with disabilities by developing methodological frameworks for hazard identification and risk assessment at the enterprise based on the analysis of the international standard DSTU IEC / ISO 31010: 2013, and the Project of carrying out by employer the occupational health and hygiene measures based on a risk-oriented approach. The employer, as the person who is legally responsible for ensuring an adequate level of safety at the workplace, is interested in implementation the effective preventive measures to prevent accidents and occupational diseases, and the risk-based approach is recognized as the most effective way to achieve this goal. The article analyzes the algorithms of the procedure for assessing occupational risks and proposes an approach to grouping risks based on the nature of the influence on the employee, place of origin, as well as environmental impact, which allows adapting the procedure to risk assessment at the workplace of different groups of workers and take into account the different conditions of persons who are directly involved in the production process.
\end{abstract}

Keywords: person with disability, safety, risk-oriented approach. 


\section{References}

1. Dyrektyva № 89/391/leES Rady shchodo zaprovadzhennia zakhodiv zaokhochennia polipshennia bezpeky ta okhorony zdorovia pratsivnykiv na roboti [Elektronnyi resurs]: stanom na 22 zhovtnia 2008 r. / Verkhovna Rada Ukrainy - Available from: https://zakon.rada.gov.ua/laws/show/994_b 23\#Text (data zvernennia 20.09.2020). Nazva z ekrana.

2. Danova K.V., Malysheva V.V. Vrakhuvannia funktsionalnykh obmezhen pry otsiniuvanni ryzyku travmuvannia pratsivnyka iz invalidnistiu / K. V. Danova, V.V. Malysheva // Komunalne hospodarstvo mist. - Vyp. 156. Kh.: KhNUMH, 2020. - S. 165-169.

3. Kontseptsiia reformuvannia systemy upravlinnia okhoronoiu pratsi [Elektronnyi resurs]: stanom na 12 hrud. 2018 r. / Verkhovna Rada Ukrainy - Available from: https://zakon.rada.gov.ua/laws/show/9892018-\%D1\%80?lang=ru (data zvernennia 11.06.2020). - Nazva z ekrana.

4. Zakon Ukrainy "Pro okhoronu pratsi» / Verkhovna Rada Ukrainy [Elektronnyi resurs]. - Available from: http://zakon2.rada. gov.ua/laws/show/2694-12 (data zvernennia 21.02.2019). - Nazva z ekrana.

5. Metodyka provedennia robotodavtsem zakhodiv z bezpeky ta hihiieny pratsi na osnovi ryzykooriientovanoho pidkhodu. Proiekt normatyvnoho dokumentu / Ofitsiinyi sait Derzhavnoi sluzhby Ukrainy z pytan pratsi [Elektronnyi resurs]. - Available from: https://dsp.gov.ua/ (data zvernennia 20.09.2020). - Nazva z ekrana.

6. Lenhardt U., Beck D. Prevalence and quality of workplace risk assessments - Findings from a representative company survey in Germany / U. Lenhardt, D. Beck // Safety Science. Volume 86, July 2016, Pages 48-56. Available from https://www.sciencedirect.com/ science/article/pii/S0925753516000618

7. Fox, M. A., Spicer, K., Chosewood, L. C., Susi, P., Johns, D. O., \& Dotson, G. S. (2018). Implications of applying cumulative risk assessment to the workplace. Environment international, 115, 230-238. DOI: 10.1016/j.envint.2018.03.026

8. Americans with Disabilities Act (42 USC 42 U.S.C. § 12101 and amendments P.L. 110325) Available from: https://www.ada.gov/ pubs/ada.htm, Accessed date: 27092020

9. U.S. Equal Employment Opportunity Commission (EEOC), 2000. Enforcement guidance: disability-related inquiries and medical examinations of employees under the Americans with Disabilities Act. Available from : https://www.eeoc.gov/policy/docs/ guidance-inquiries.html, Accessed date: 27 092020

10. Marie Laberge, Bénédicte Calvet, Marc Fredette, Nassim Tabet, AurélieTondoux, Dolores Bayard, Curtis Bresline Unexpected events: Learning opportunities or injury risks for apprentices in low-skilled jobs? A pilot study. Safety Science. Volume 86, July 2016, Pages 1-9 Available from: https://www. sciencedirect.com/science/article/pii/S0925 753516000424

11. Yanar, B., Lay, M., Smith, P.M., 2019. The Interplay Between Supervisor Safety Support and Occupational Health and Safety Vulnerability on Work Injury. Safety and Health at Work. DOI: 10.1016/j.shaw.2018.11.001

12. DSTU IEC/ISO 31010:2013 Keruvannia ryzykom. Metody zahalnoho otsiniuvannia ryzyku (IEC/ISO 31010:2013, IDT). Kyiv: Minekonomrozvytku Ukrainy, 2015.

13. Identyfikator vyrobnychykh nebezpek i stvoriuvani nymy vyrobnychi ta profesiini ryzyky na obiektakh riznykh haluzei ekonomiky. Proiekt normatyvnoho dokumentu / Ofitsiinyi sait Derzhavnoi sluzhby Ukrainy z pytan pratsi [Elektronnyi resurs]. - Available from: https://dsp.gov.ua/ (data zvernennia 20.09.2020).

14. Danova K.V. Funktsionalni obmezhennia osib iz invalidnistiu $v$ aspekti otsinky rivnia pratsezdatnosti ta bezpeky pratsi. Komunalne hospodarstvo mist. Vyp. 7 (146). Kharkiv: KhNUMH, 2019. S. 133-137. 